\title{
Bead Flow Injection-Spectrophotometric System for Determination of Paracetamol using N-Bromosuccinimide and Methyl Orange as Reagent and it Application
}

\author{
Khdeeja Jabbar Ali and Nadia Mahdi Muslim \\ Department of Chemistry, Faculty of Education for Girls, University of Kufa, Kufa, Iraq \\ khdijajabar@gmail.com, aln7914@gmail.com,07825892860
}

\begin{abstract}
A new system was designed using a column filled with beads (silica gel) properties to determination Paracetamol (PCT) using a reagent N-Bromosuccinimide (NBS) and methyl orange the reaction is done according to the process of oxidation and reduction the wavelength was determined at $\lambda_{\max } 507 \mathrm{~nm}$. It was studied physical and chemical variables of the reaction such as such as the of flow rate and weight beads and study the effect of reaction time of saturated and effect of the reaction coil length. It has been found that the optimal concentration of hydrochloric acid $0.5 \mathrm{~mol} / \mathrm{L}$ and $\mathrm{KBr} 2 \%$ and the methyl orange concentration $8 \times 10^{-4}$ $\mathrm{mol} / \mathrm{L}$ and NBS $0.05 \mathrm{~mol} / \mathrm{L}$ and study the volume of methyl orange, the detection limit was (3 readings of blank) where the value was equal to $0.0148 \mathrm{mg} / \mathrm{L}$, the technique has been successfully applied to determination PCT in multiple pharmaceutical samples.
\end{abstract}

Key words: Suspension of particles in flow analysis in technique, Paracetamol (PCT), pharmaceutical samples, hydrochloric acid, N-Bromosuccinimide (NBS), silica gel

\section{INTRODUCTION}

Paracetamol (PCT) (acetaminophen-acetyl-p-amino phenol) painkiller and antipyretic for children who develop viral infection and does not affect platelet function, it is a suitable medication for patients suffering from stomach pain they do not need an anti-inflammatory (Whalen et al., 2015; Santos et al., 2015). A substantial doses of PCT cause organ failure within hours it is absorbed through the gastrointestinal tract then partially converted to liver and excreted (4\%) without any change in kidneys and is used to treat the light to moderate pain (Santos et al., 2015). PCT was first produced in 1955, drug children's hypothermia in laboratories McNeil (Tylenol children's elixir) (Benista and Nowak, 2014). It is a medication Non-Steroidal Anti-Inflammatory (NSADs) (Graham et al., 2013). Where the PCT toxicity of seronegative hepatitis supports the central nervous system and heart systems and kidney and patients with ALF vulnerable to infection and patients who do not use PCT inhibitors are sufficient to relieve pain (Walker and Whittlesea, 2012). Uses a residence additional with a tramadol and strong with morphine, fentanyl the use of non-steroidal anti-inflammatory drugs is prevented for cases gastric ulcers allergies of aspirin, blood clotting, pregnant women and fever of children. Many people do not feel PCT poisoning within $24 \mathrm{~h}$ and when taking the over dose symptoms of abdominal pain and nausea with increased PCT toxicity and person suffering from liver failure characterized by low blood sugar, hepatic encephalopathy and lack of acidity in the blood, increased toxicity PCT with excessive alcoholin take or anorexia as well as with isoniazid (Vidhya and Bai, 2012; Dhshan, 2014). Its solubility in water is $70 \%$ at room temperature dissolve in boiled water 1 in 20 portions (Kalantzi et al., 2006). Therapeutic dose is allowed for adults the $0.5-1 \mathrm{~g}$ limit $4 \mathrm{~g} /$ day and children $10-15 \mathrm{mg} / \mathrm{kg}$ all 4-6h (Ibrahim et al., 2013). This suspension of particles in flow analysis in technique was discovered in the middle 1990's of before of Ruziickaa and colleagues were used in various applications and flow injection systems advanced (Ruzicka et al., 1993). The volume of solid particles depend chemical properties on the type of flow system and the analytical application it is characterized by being solid particles aspherical shape and their small size with a diameter of 10-200 $\mathrm{mm}$ this method is used in medicine, Biology and Chemistry (Shapiro, 2003). The volume of the suspended solution used is $2-10 \mathrm{~mL}$ and contains 2000-10000 beads to SIA limitation with magnetic beads the suspended volume can be used more than $150 \mathrm{~mL}$ and it works with concentration $25 \mathrm{mg} / \mathrm{mL}$ (Trojanowicz, 2008). The addition of methylene (2-CDHPMA) mg/SWCNTs and 2-Chloro-N-(2.5-dihydroxyphenyl) to the carbon paste and the bologue was analyzed in different samples glutathione was analyzed. Electro physiological interaction between 2-CDHPMA and glutathione was

Corresponding Author: Khdeeja Jabbar Ali, Department of Chemistry, Faculty of Education for Girls, University of Kufa, Kufa, Iraq khdijajabar@gmail.com, 07825892860 
used the range was linearly dynamic ranging from $0.05-700.0 \mu \mathrm{mol} / \mathrm{L}$. The surface of the carbon swivel (CPE), Cetyl Trimethylamonium Bromide (CTAB), the CTAB-DCF reaction it performs electrolyte oxidation of (DCF) in the absence of (CTAB) technology spectrophotometric and electrochemical (Guzman-Hernandez et al., 2017). The nano rods were developed where $\mathrm{BiO}$ was poured on electrodes made of graphite (BiO-SPEs) for the passage of ultra violet radiation to estimate acetaminophen (APAP) a common overlap was found in isoniazid $(\mathrm{INH})$ that the sensor pads $\mathrm{BiO}-\mathrm{SPEs}$ provide a potential candidate for APAP and NH estimates accurately in pharmaceutical samples (Mahmoud et al., 2017). This method was used to estimate the dissolved amount of acetaminophen (\%), the solubility time $(20-40 \mathrm{~min})$ the volume (from $800-1000 \mathrm{~mL}$ ) and $(\mathrm{pH}$ ) (from 2.0-6.8) and solubility (from 40-60 rpm) the utilize Monte Carlo simulations (Romero and Lourenco, 2017).

\section{MATERIALS AND METHODS}

Apparatus: Shimadzu UV-1700 spectrophotometer, spectrophotometer labomed. InG single beam, USA, spectrophotometer, analytically equilibrium sentient Denveri Stamping, Recorder Pen Siemens C 1032, Hitter thermic Ardeas 51, peristaltic pump Germany, Ismatic, coils interaction with the radius of $0.5 \mathrm{~mm}$, house hold taps, pipingcargo of Teflon, inflow cell size of $450 \mu \mathrm{L}$. Column mead of Teflon, beads (silica gel) properties.

\section{Chemicals materials}

PCT $\left(\mathrm{C}_{8} \mathrm{H}_{9} \mathrm{NO}_{2}\right.$, M.wt. $\left.151.17 \mathrm{~g} / \mathrm{mol}\right)$ stock solution: A $100 \mathrm{mg} / \mathrm{L}$ standard PCT stock solution was prepared by dissolving $0.01 \mathrm{~g}$ PCT in distilled water and diluting quantitatively to $100 \mathrm{~mL}$ with distilled water. Appropriate dilutions were prepared from the standard solutions.

Potassium bromide $\mathrm{KBr}$ solution: The 1\% solution was prepare by dissolve $1 \mathrm{~g}$ of $\mathrm{KBr}$ with $100 \mathrm{~mL}$ distilled water in suitable a flask volume.

N-Bromosuccinimide (NBS) $\left(\mathrm{C}_{4} \mathrm{H}_{4} \mathrm{BrNO}_{2}\right.$, M.wt. 177.98 g/mol) solution: The $0.1 \mathrm{~mol} / \mathrm{L}$ solution was prepared by dissolving $1.7798 \mathrm{~g}$ of NBS and diluting quantitatively to $100 \mathrm{~mL}$ with distilled water.

Methyl orange $\left(\mathrm{C}_{14} \mathrm{H}_{14} \mathrm{~N}_{3} \mathrm{NaO}_{3} \mathrm{~S}\right.$, M.wt. $\left.327.33 \mathrm{~g} / \mathrm{mol}\right)$ : The $5 \times 10^{-4} \mathrm{~mol} / \mathrm{L}$ solution was prepared by dissolving $0.01636 \mathrm{~g}$ of methyl orange and diluting quantitatively to $100 \mathrm{~mL}$ with distilled water.

Hydrochloric acid HCI solution: The $0.5 \mathrm{~mol} / \mathrm{L}$ solution was prepare by dissolved $4.47 \mathrm{~mL}$ of concentrated acid in $100 \mathrm{~mL}$ distilled water in a flask volume (This solution must be standardization).

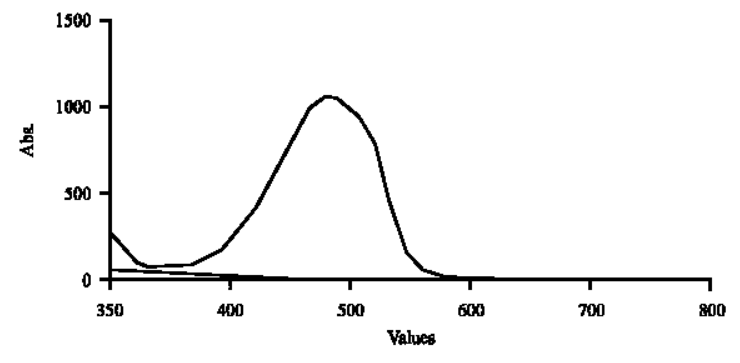

Fig. 1: UV-Vis spectroscopy for PCT with NBS

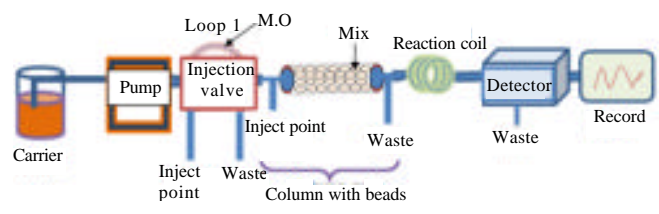

Fig. 2: The new design of the suspension of particles system FIA

Determination of the wavelength for maximum absorption for product of reaction: Ultraviolet visible spectroscopy was used to determine the wavelength of maximum absorption of the compound. It was the $\lambda_{\max }$ composite of $507 \mathrm{~nm}$ shown in Fig. 1.

Design of FIA system: A new injection valve consisting of 6 secondary valves is designed. Each secondary valve has 3 exits. The new valve is connected to a pump and column containing beads (silica gel) and coils reaction and detector to specify the signal and record the form is download methyl orange loaded in loop Teflon of a secondary valve and download mix solution in the column, shown in Fig. 2.

\section{RESULTS AND DISCUSSION}

\section{Optimization}

Effect of the weight beads: Various weights of beads were used to determine the peak height of the optimum weights between (0.0828-0.3312 g), the optimum weight was $(0.3312 \mathrm{~g})$ than a decrease in peak height to due lack measurement sensitivity as in Fig. 3. Prepare a mix in this study $5 \mathrm{~mL}$ of PCT the beads saturated by mixture of PCT solution which form $10 \mathrm{ppm}$ and add $0.5 \mathrm{~mL}$ of $\mathrm{HCl} 0.5 \mathrm{~m}$ concentration and $1 \mathrm{~mL}$ from NBS $0.1 \mathrm{~m}$ and $0.5 \mathrm{~mL}$ from $1 \% \mathrm{KBr}$. The volume is then supplemented with distilled water in a $10 \mathrm{~mL}$ volume container and left for $10 \mathrm{~min}$.

Effect of the time which required to saturated of beads: The effect of time on the peak height was studied for the completion of the reaction and highly stable. It was 

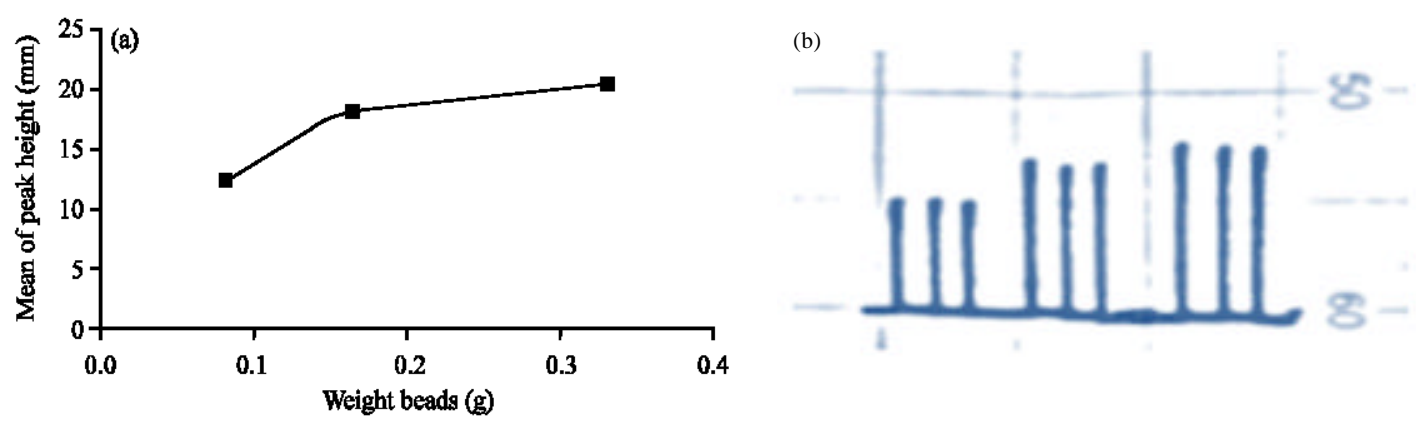

Fig. 3: a, b) Change of peak height with weight beads in column a using the new FIA unit
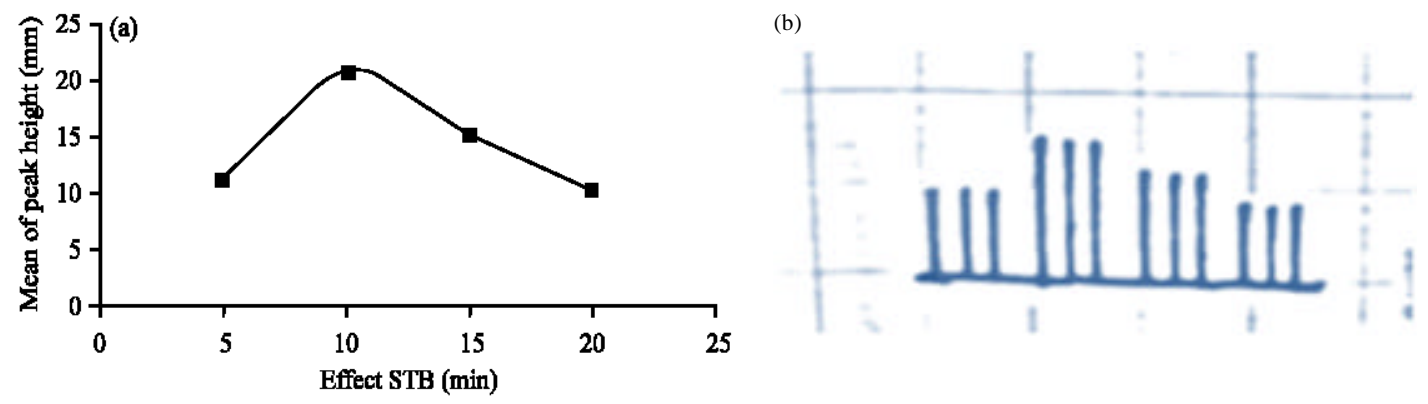

Fig. 4: a, b) Change of peak height with time saturated of beads a using the new FIA unit

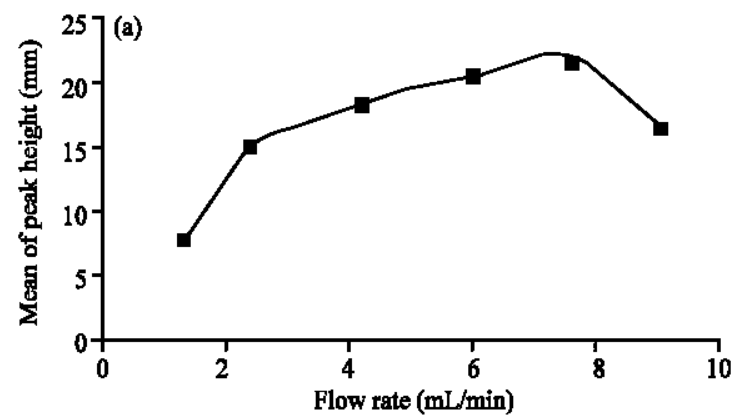

(b)

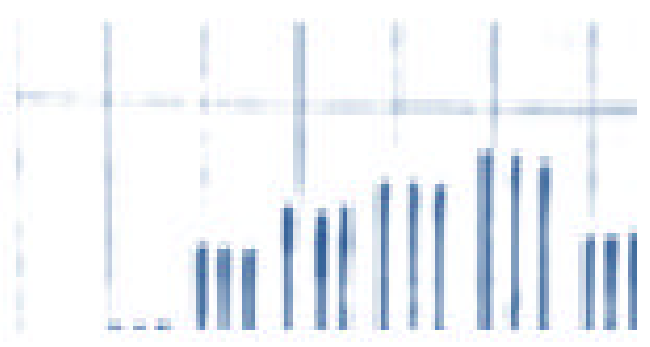

Fig. 5: a, b) Change of peak height with flow rate a using the new FIA unit

between $(5-20 \mathrm{~min})$. The optimum time was $10 \mathrm{~min}$, completion of the process oxidation of PCT the after this time peak height decreased because of the less sensitive the measurement as in Fig. 4.

Effect of the flow rate: Study the effect of the flow rate at peak height with in the range $(1.3-9.1 \mathrm{~mL} / \mathrm{min})$ the flow rate was optimal $(7.6 \mathrm{~mL} / \mathrm{min})$ then it decreased peak height because of the lack of measurement sensitivity and incomplete oxidation-reduction reaction as in Fig. 5.

Effect of the reaction coil length: The effect of the reaction coil length within the range $(10-40 \mathrm{~cm})$ were studied at the peak height. The reaction coil length $20 \mathrm{~cm}$ was optimal as a result of the completion of the reaction and after this length reduce peak height as in Fig. 6.
Effect of the methyl orange volume: Different methyl orange volume was used between $(78.500-395.500 \mu \mathrm{L})$ to know the best volume and the volume that gave higher peak height was $(235.500 \mu \mathrm{L})$ as a result of good homegeneone in the zone and after this volume decreased in height peak due to less of measurement sensitivity as in Fig. 7.

Effect of the hydrochloric acid concentration: Multiple of hydrochloric acid concentrations have been prepared with in range $(0.1-1.5 \mathrm{~mol} / \mathrm{L})$ the results indicated that the optimum concentration was $0.5 \mathrm{~mol} / \mathrm{L}$ which gave higher peak height this concentration was sufficient oxidation for the PCT and after the concentration this decreased peak height due to low sensitivity as in Fig. 8. 


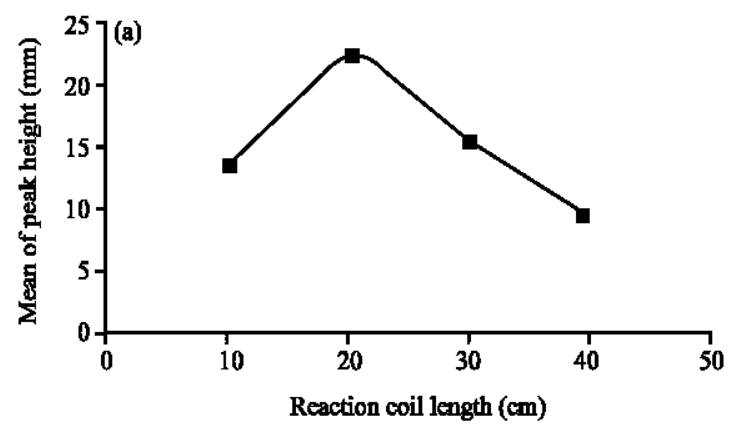

(b)

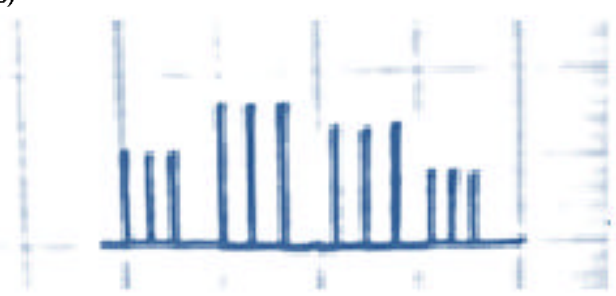

Fig. 6: a, b) Change of peak height with the reaction coil length a using the new FIA unit

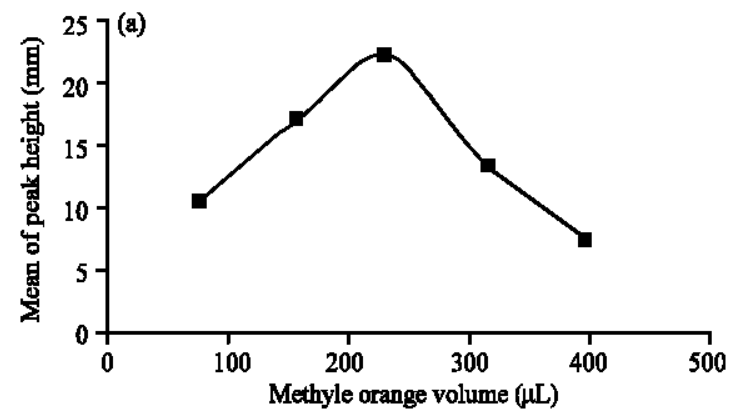

(b)

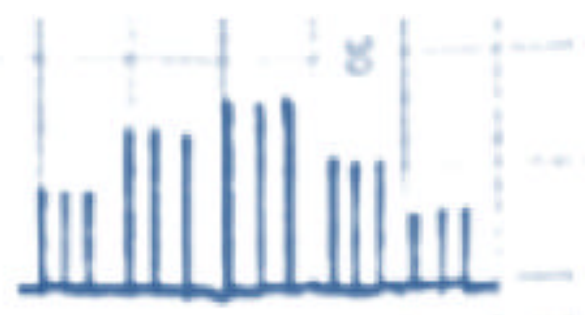

Fig. 7: a, b) Change of peak height with the methyl orange volume a using the new FIA unit

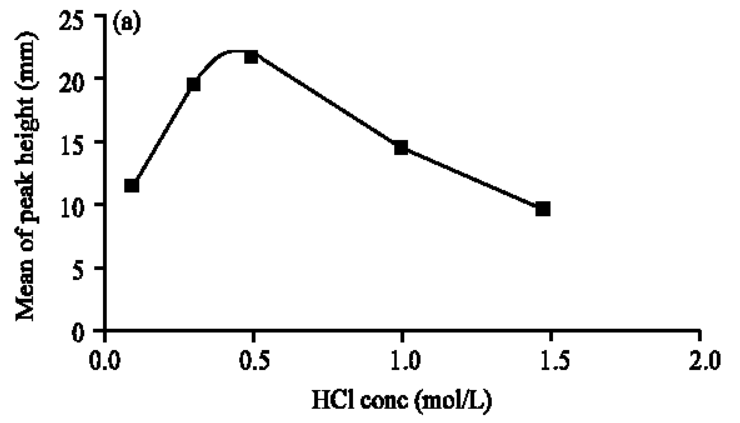

(b)

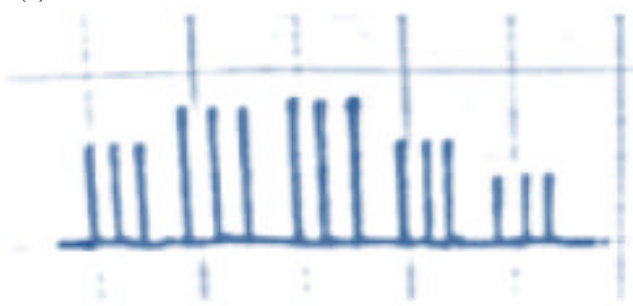

Fig. 8: $\mathrm{a}, \mathrm{b}$ ) Change of peak height with the $\mathrm{HCl}$ concentrations a using the new FIA unit

Effect of the potassium bromide concentration: Study the concentration effect ofthe potassium bromide concentration within the range $(0.01-4 \%)$. The best concentration $2 \%$ to give the higher peak was to accelerate the process of oxidation of PCT as in Fig. 9.

Effect of the methyl orange concentration: Change of the methyl orange concentration was studied between $\left(1 \times 10^{-4}-1 \times 10^{-3} \mathrm{~mol} / \mathrm{L}\right)$, the optimal concentration was found $\left(8 \times 10^{-4} \mathrm{~mol} / \mathrm{L}\right)$ to give the higher peak was to accelerate the process of oxidation of PCT and after this concentration decreased the peak height as in Fig. 10.
Effect of the NBS concentration: Various concentrations ofthe NBS prepared within range $(0.01-0.5 \mathrm{~mol} / \mathrm{L})$ found that the concentration was optimal $(0.05 \mathrm{~mol} / \mathrm{L})$ to give the higher peak to get the process oxidation of PCT and after that this concentration the peak height decreased due to low measurement sensitivity as in Fig. 11.

Effect of the acid type: Different types of acids were selected in $\mathrm{HCl}, \mathrm{H}_{2} \mathrm{SO}_{4}$ and $\mathrm{CH}_{3} \mathrm{COOH}$ with concentration $0.5 \mathrm{~mol} / \mathrm{L}$ to study its effect on PCT oxidation where the results indicate that $\mathrm{HCl}$ acid was the best oxidation of the drug to give the higher peak as in Fig. 12. 

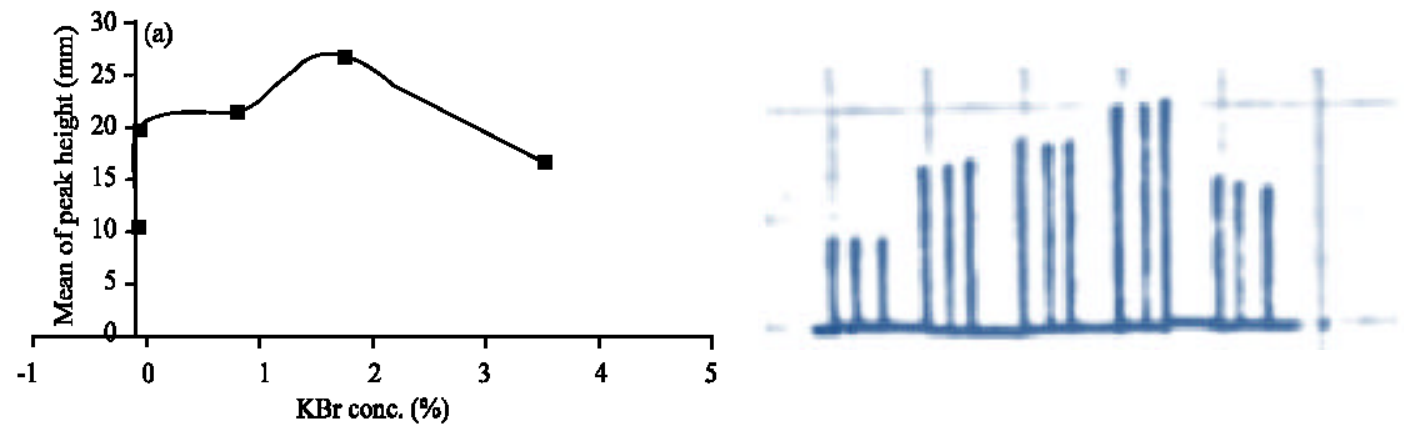

Fig. 9: a, b) Change of peak height with $\mathrm{KBr}$ concentrations a using the new FIA unit
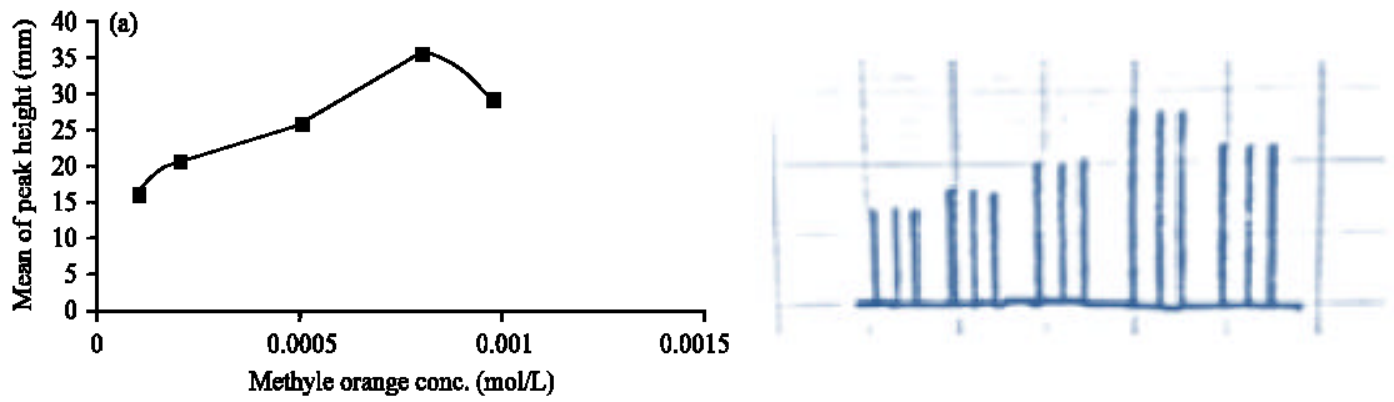

Fig. 10: a, b) Change of peak height with methyl orange concentrations a using the new FIA unit

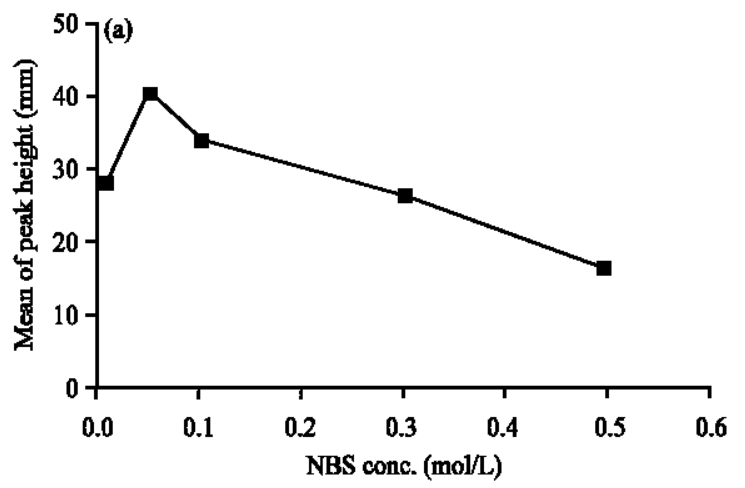

(b)

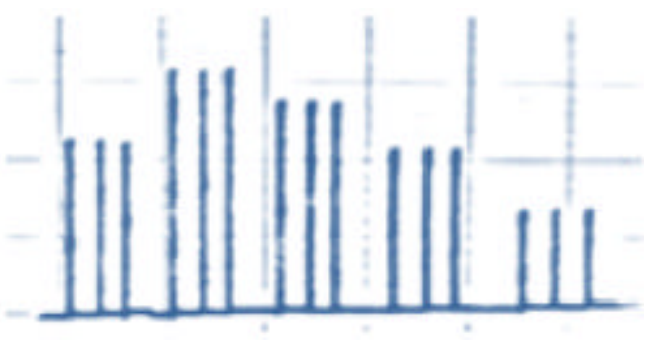

Fig. 11: a, b) Change of peak height with NBS concentrations a using the new FIA unit

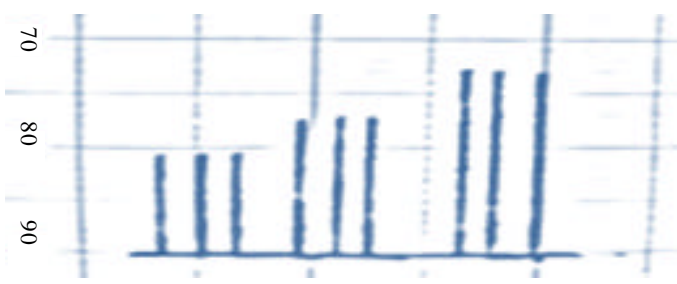

$\mathrm{H}_{2} \mathrm{SO}_{4} \mathrm{CH}_{3} \mathrm{COOOH} \mathrm{HCl}$

Fig. 12: Change of peak height with acid type a using the new FIA unit

Calibration curve: After determining optimal conditions for the reaction, the process of oxidation PCT the calibration curve has been prepared, I attended a series of PCT concentrations to know the linearity and obedience to the Law of Beer-Lambert. It is clear that the linearity range is between $1-10 \mathrm{mg} / \mathrm{L}$ a negative deviation was then observed by a decrease in the peak height of the recorded after this concentration the detection limit was ( 3 readings of blank) where the value was equal to $0.0148 \mathrm{mg} / \mathrm{L}$ as in Fig. 13 .

Repeatability: To find out how the results match an efficient system designed, this study was performed using a concentration of $10 \mathrm{mg} / \mathrm{L}$ of $\mathrm{PCT}$, at optimamuine conditions and indicate of results to adjust measurements using the system designed as in Fig. 14. 

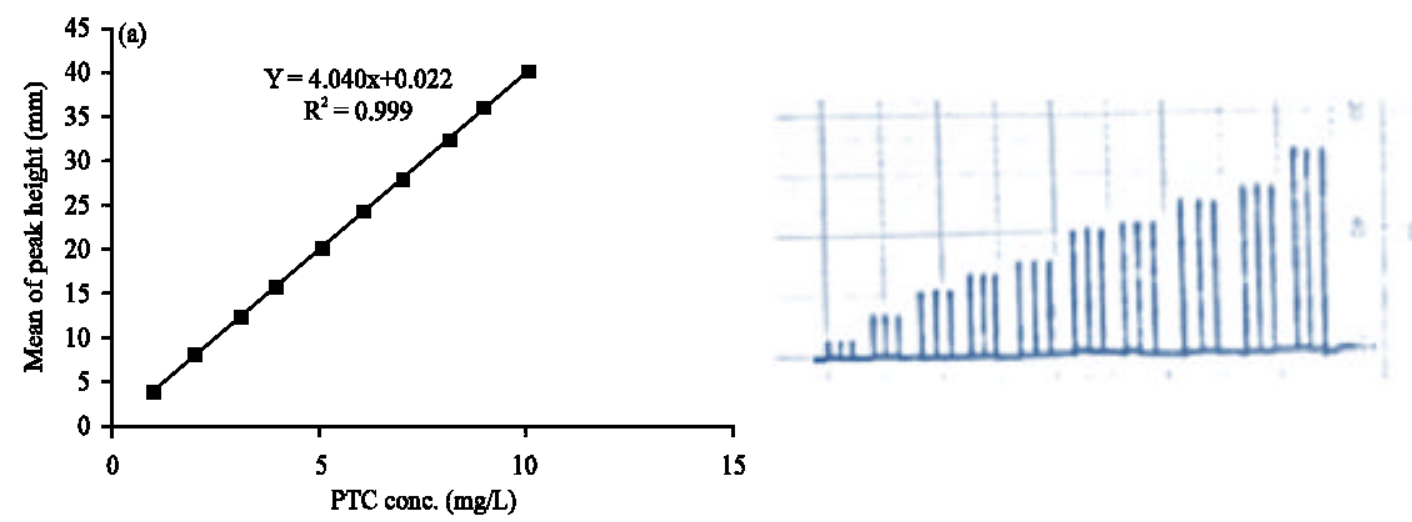

Fig. 13: a, b) Calibration curve of the PCT a using the new FIA unit
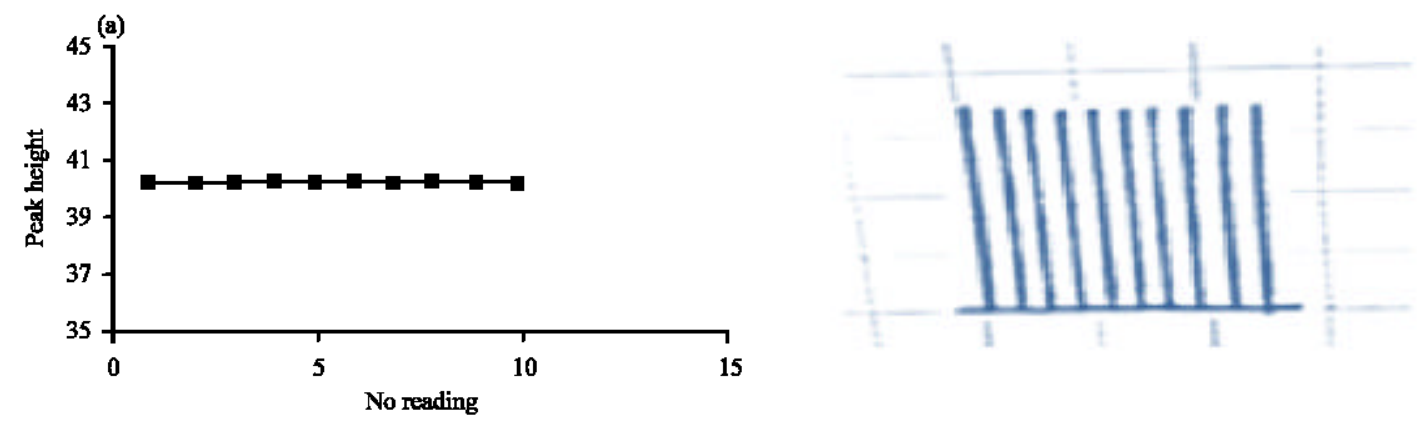

Fig. 14: a, b) Repeatability ofthe PCT for $10 \mathrm{mg} / \mathrm{L}$ ausing the new FIA unit

Determination of dispersion: Dispersion was measured for PCT at 2 concentration of $(5.10 \mathrm{mg} / \mathrm{L})$ two trials were conducted the first experience mix the mixture with anmethyl orange and pass through the system to give continuous response and this indicates the dispersion is not affected by convection or diffusion; The measurement is represented $\left(\mathrm{H}^{\circ}\right)$; The second experiment injects different concentrations of PCT $(5.10 \mathrm{mg} / \mathrm{L})$ the value obtained is $\left(\mathrm{H}_{\max }\right)$ represents (D) the dispersion coefficient and was calculated from the following equation $(D)$ is: $\mathrm{D}=\mathrm{H}^{\circ} / \mathrm{H}_{\max }$. These values represent the limit status of dispersion as in Table 1 and Fig. 15.

Effect of interferences: Study the effect of the interferences compounds of the following (ascorbic acid, citric acid, $\mathrm{Na}_{2} \mathrm{CO}_{3}, \mathrm{CH}_{3} \mathrm{COOH}$, aspirin) on the process of oxidation and reduction of $\mathrm{PCT}$, the concentration of the interferences material $(10,50 \mathrm{mg} / \mathrm{L})$ and concentration of the PCT $10 \mathrm{mg} / \mathrm{L}$ and the results indicated the interfering substances do not effect on the process of oxidation and reduction as in Table 2 (Mehretie et al., 2011).

Applications: After determining optimal conditions for reaction this method has been applied to estimate

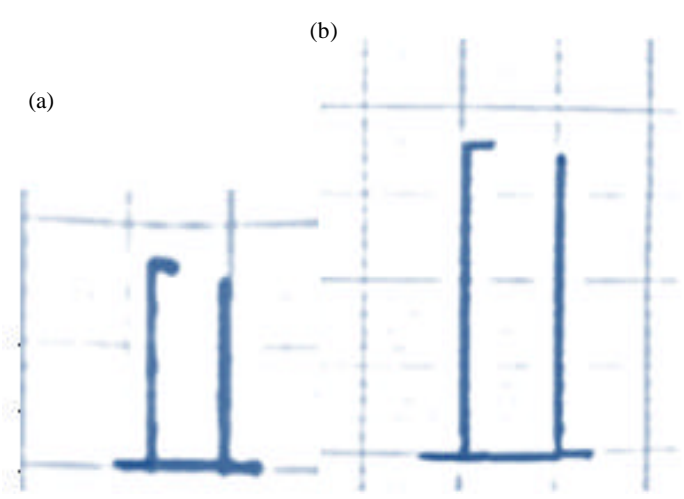

Fig. 15:a, b) The dispersion coefficient of PCT a using the new FIA unit; a) $5 \mathrm{mg} / \mathrm{L}$ and b) $10 \mathrm{mg} / \mathrm{L}$

Table 1: Determination of dispersion of the PCT

\begin{tabular}{llcc}
\hline & Response $(\mathrm{mm})$ & \\
PCT concentration & - & & \\
$(\mathrm{mg} / \mathrm{L})$ & $\mathrm{H}^{0}$ & $\mathrm{H}_{\max }$ & Dispersion $(\mathrm{D})\left(\mathrm{D}=\mathrm{H}^{0} / \mathrm{H}_{\max }\right)$ \\
5 & 21.780 & 20.370 & 1.069 \\
10 & 41.370 & 40.240 & 1.028 \\
\hline
\end{tabular}

PCT in different pharmaceutical samples and the recovery values were for the samples determined as in Table 3 (Al-Abachi et al., 2015). 
Table 2: Determination of interferences of the PCT

\begin{tabular}{lccc}
\hline Interferences & $\begin{array}{c}\text { Conc. interferences } \\
(\mathrm{mg} / \mathrm{L})\end{array}$ & $\begin{array}{c}\text { Conc. PCT } \\
(\mathrm{mg} / \mathrm{L})\end{array}$ & $\begin{array}{c}\text { The change in } \\
\text { peak height }\end{array}$ \\
\hline Ascorbic acid & 10 & 10 & -0.080 \\
& 50 & 10 & +0.620 \\
Citric acid & 10 & 10 & +0.123 \\
& 50 & 10 & +0.530 \\
$\mathrm{Na}_{2} \mathrm{CO}_{3}$ & 10 & 10 & -0.060 \\
& 50 & 10 & +0.690 \\
$\mathrm{CH}_{3} \mathrm{COOH}$ & 10 & 10 & +0.187 \\
& 50 & 10 & +0.740 \\
Aspirin & 10 & 10 & +0.093 \\
& 50 & 10 & +0.390 \\
\hline
\end{tabular}

Table 3: Applications of determinate the PCT in different pharmaceutical sample

\begin{tabular}{|c|c|c|c|}
\hline Pharmaceutical samples & $\begin{array}{c}\text { The take } \\
\text { value }(\mathrm{mg} / \mathrm{L})\end{array}$ & $\begin{array}{l}\text { The found } \\
\text { value (mg/L) }\end{array}$ & $\begin{array}{c}\text { Recovery } \\
(\%) \\
\end{array}$ \\
\hline $\begin{array}{l}\text { Panadolextra, made } \\
\text { (Glaxosmithkline) Ireland }\end{array}$ & 10 & 10.067 & 100.670 \\
\hline $\begin{array}{l}\text { Kanagesic, made } \\
\text { (Kanawati medical producte) Syria }\end{array}$ & 10 & 10.032 & 100.320 \\
\hline $\begin{array}{l}\text { Saridon, made (Bayer consumer } \\
\text { care AG basel) Switzerland by } \\
\text { Gaillard, France }\end{array}$ & 10 & 10.035 & 100.350 \\
\hline Antipyrol made (Iraq-Samarra) & 10 & 10.043 & 100.430 \\
\hline $\begin{array}{l}\text { Cold-Med, made (Mediphar } \\
\text { laboratories) Lebanon }\end{array}$ & 10 & 10.049 & 100.490 \\
\hline $\begin{array}{l}\text { Emidol made (Globalpharma } \\
\text { Co.L.L.C) Dubai, UAS }\end{array}$ & 10 & 10.065 & 100.650 \\
\hline Paracetamol injection & 10 & 10.009 & 100.090 \\
\hline
\end{tabular}

\section{CONCLUSION}

From this study and recovery values can conclusion the accuracy of this method for PCT determined and efficiency new FIA unit.

\section{ACKNOWLEDGEMENTS}

I would like to thank the magazine for agreeing to publish the research and everyone who contributed, show the search in the final form.

\section{REFERENCES}

Al-Abachi, M.Q., S.A. Al-Safi and H.S. Al-Ward, 2015. Spectrophotometric kinetic methods for the determination of Paracetamol in pure form and pharmaceutical preparations. Iraqi J. Sci., 56: 2704-2717.

Benista, M.J.B. and J.Z. Nowak, 2014. Paracetamol: Mechanism of action, applications and safety concern. Acta Poloniae Pharm. Drug Res., 71: 11-23.

Dhshan, D.H., 2014. [Pharma Guide Basic and Clinical Pharmacology]. 3rd Edn., Pharma Guide Publishing Company, Karachi, Pakistan, ISBN:9772032880,.

Graham, G.G., M.J. Davies, R.O. Day, A. Mohamudally and K.F. Scott, 2013. The modern pharmacology of paracetamol: Therapeutic actions, mechanism of action, metabolism, toxicity and recent pharmacological findings. Inflammopharmacology, 21: 201-232.
Guzman-Hernandez, D.S., M.M. Cid-Ceron, M. Romero-Romo, M.T. Ramirez-Silva and M.E. Paez-Hernandez et al., 2017. Taking advantage of CTAB micelles for the simultaneous electrochemical quantification of diclofenac and acetaminophen in aqueous media. RSC. Adv., 7: 40401-40410.

Ibrahim, T., S. Agnihotri and A.K. Agnihotri, 2013. Paracetamol toxicity-An overview. Emergency Med. Open Access, 3: 1-3.

Kalantzi, L., C. Reppas, J.B. Dressman, G.L. Amidon and H.E. Junginger et al., 2006. Biowaiver monographs for immediate release solid oral dosage forms: Acetaminophen(Paracetamol). J. Pharm. Sci., 95: 4-14.

Mahmoud, B.G., M. Khairy, F.A. Rashwan and C.E. Banks, 2017. Simultaneous voltammetric determination of acetaminophen and isoniazid (Hepatotoxicity-Related drugs) utilizing bismuth oxide nanorod modified screen-printed electrochemical sensing platforms. Anal. Chem., 89: $2170-2178$.

Mehretie, S., S. Admassie, M. Tessema and T. Solomon, 2011. Voltammetric determination of paracetamol with poly (3,4-ethylenedioxythiophene) modified glassy carbon electrode. Anal. Bioanal. Electrochem., 3: 38-50.

Romero, D.C. and F.R. Lourenco, 2017. Measurement uncertainty of dissolution test of acetaminophen immediate release tablets using Monte Carlo simulations. Braz. J. Pharm. Sci., 53: 1-9.

Ruzicka, J., C.H. Pollema and K.M. Scudder, 1993. Jet ring cell: A tool for flow injection spectroscopy and microscopy on a renewable solid support. Anal. Chem., 65: 3566-3570.

Santos, A.M., F.C. Vicentini, P.B. Deroco, R.C. Rocha-Filho and O. Fatibello-Filho, 2015. Square-wave voltammetric determination of paracetamol and codeine in pharmaceutical and human body fluid samples using a cathodically pretreated boron-doped diamond electrode. J. Braz. Chem. Soc., 26: 2159-2168.

Shapiro, H.M., 2003. Practical Flow Cytometry. 4th Edn., Wiley, Hoboken, New Jersey, USA., ISBN:9780471411253, Pages: 736.

Trojanowicz, M., 2008. Advances in Flow Analysis. John Wiley \& Sons, Hoboken, New Jersey, USA., ISBN:9783527623266, Pages: 702.

Vidhya, M.H.L. and M.M. Bai, 2012. Beware of Paracetamol toxicity. J. Clin. Toxicol, 2: 142-144.

Walker, R. and C. Whittlesea, 2012. Clinical Pharmacy and Therapeutics. 5th Edn., Elsevier, London, UK., ISBN-13:9780702042935, Pages: 983.

Whalen, K., R. Finkel and T.A. Panavelil, 2015. Lippincott Illustrated Wolters Kluwer, Alphen aan den Rijn, SouthHolland,Netherlands,ISBN:978-1-4511-9177-6, Pages: 664. 